\title{
EXCLUDING FORCED HEIRS DUE TO A LACK OF PERSONAL RELATIONSHIP WITH THE DECEASED IN SPAIN IN A COMPARATIVE PERSPECTIVE
}

\author{
Rosa M. Garcia-Teruel ${ }^{*}$
}

\begin{abstract}
Forced heirship is considered a limit on the freedom of will of the deceased in favour of intergenerational solidarity. It involves that some relatives, usually descendants, have the right to claim a share of the deceased's assets or estate. Although recognized in most EU jurisdictions, authors discuss about the need to regulate this institution taking into account new family models and societal changes. In fact, this debate has been intensified due to the COVID-19 pandemic, which showed that several elders died alone in nursing homes without family support, and part of their assets shall be reserved to their relatives. This paper analyses the legal framework of forced heirship in Spain and examines to which extent it is possible to exclude this right due to a lack of personal relationship with the beneficiaries in view of comparative models.
\end{abstract}

Keywords: forced heirship, family relationships, familiar solidarity, inheritance

\section{INTRODUCTION}

During 2020, the COVID-19 pandemic added significance to the debate about family and intergenerational solidarity: at a first step of the pan-

Dr. Rosa M. Garcia-Teruel, Postdoctoral researcher at the UNESCO Housing Chair, Rovira i Virgili University; correspondence address: Av. Catalunya, 35. 43002 Tarragona, Spain; e-mail: rosamaria.garciat@urv.cat; https://orcid.org/0000-0002-3215-4608. 
demic, people living in nursing homes were the most affected by the virus, since more than 19,000 people died in these institutions in Spain between March 2020-2021 ${ }^{1}$. The worst situation occurred at the beginning of the pandemic, since the lack of sanitary measures and health equipment caused massive deaths, the closure of these centres and therefore isolation and lock down of the elderly there, who were obliged to live in their rooms or in reduced spaces for months ${ }^{2}$. The situation was not different in other EU Countries: in Ireland, over a third of COVID-19 deaths were linked to nursing homes ${ }^{3}$, while in the Netherlands and Germany ${ }^{4}$ deaths in these institutions represented more than a half of total COVID-19 casualties 5 .

Once the elderly people in nursing homes were able to leave or, at least, to have a less restrictive movement regime, some of them noticed with more intensity the lack of family support, which is one of the key factors that leads to loneliness and depression in this sector of population ${ }^{6}$. But this lack of family support was not caused by the pandemic itself, but a trend in our post-traditional society, in which the traditional family care has been replaced by modern welfare state's protections against disability and illnesses ${ }^{7}$.

1 Data from IMSERSO. Actualización no 4. Enfermedad por coronavirus (COVID-19) en Centros Residenciales. 4.4.2021. Available at: https://www.imserso.es/InterPresent1/groups/imserso/documents/binario/inf_resid_20210312.pdf.

2 Spain. Order SND/265/2020, 19 March, de adopción de medidas relativas a las residencias de personas mayores y centros socio-sanitarios, ante la situación de crisis sanitaria ocasionada por el COVID-19. BOE No. 78, 21.3.2020.

3 The Irish Times. Covid-19: Over a third of February deaths linked to nursing homes. 9.2.2021. Available at: https://www.irishtimes.com/news/health/covid-19-over-athird-of-february-deaths-linked-to-nursing-homes-1.4479497.

4 Berlin.de. Fast zwei Drittel der Corona-Toten sterben im Pflegeheim. 27.1.2021. Available at: https://www.berlin.de/aktuelles/berlin/6426787-958092-fast-zwei-drittelder-coronatoten-sterbe.html.

5 RTLNieuws. Aantal coronadoden boven de 6000, bijna de helft overleed in verpleeghuis. 5.6.2020. Available at: https://www.rtlnieuws.nl/nieuws/artikel/5144186/corona-doden-sterfgevallen-overleden-verpleeghuis-ouderen.

6 Joan Domènech-Abella et al., "Loneliness and Depression in the Elderly: The Role of Social Network," Social Psychiatry and Psychiatric Epidemiology 52, no. 4 (April 2017): 381-90. https://doi.org/10.1007/s00127-017-1339-3.

7 Ronald J. Angel and Jaqueline Angel, Family, intergenerational solidarity and post-traditional society (New York and London: Routledge, 2018), 9. 
One of the mechanisms that states use to ensure intergenerational solidarity ${ }^{8}$ is through successions law. Succession law varies among Europe, but most EU countries, like Belgium, France, Germany or Austria," regulate forced heirship or reserved shares of the inheritance, which limit the freedom to dispose of property upon death. This is usually an ius cogens measure to protect property interests of persons close to the testator ${ }^{10}$, and has its origins in Roman Law (querella inoffciosi testamenti) ${ }^{11}$. As Kristić mentions ${ }^{12}$, according to the support alimony theory, the compulsory share would aim to 'ensure and continue support from the inherited property for the persons that a testator had the obligation to support in his or her lifetime'.

Nevertheless, during last few years some authors in different jurisdictions proposed either the abolition of forced shares ${ }^{13}$ or introducing more grounds to exclude forced heirs, often influenced by common law systems, considering that current family models do not fit into this institution. In fact, forced heirship was introduced to protect especially minor children, but current life expectancy makes forced heirs inherit when they are nearly in their sixties ${ }^{14}$. In fact, as seen below, the attribution of a forced shared

8 Intergenerational solidarity is defined as the social cohesion between generations. Vern Bengston, Gerardo Marti, and Robert Roberts, "Age-group relationships: Generational equity and inequity," in Parent-child relations throughout life (New York and London: Routledge, 1991), 283-308.

9 See the differences in these regimes in the e-Justice portal: https://e-justice.europa. eu/content_successions-166-en.do.

10 Novak Krstić, "A doctrinal justification of the institution of compulsory share in modern legislature," Teme, no. 10 (February 2020), https://doi.org/10.22190/TEME200207092K.

11 Ángel M. López López and Rosario Valpuesta Fernández, eds., Derecho de sucesiones (Valencia: Tirant lo Blanch, 2015), 114.

12 Ibid.

13 Josefina Alventosa Del Río et al., "Aspectos sustantivos del derecho hereditario," in Derecho de sucesiones, ed. Josefina Alventosa Del Río and María Elena Cobas Cobiella (Valencia: Tirant lo Blanch: 2017), 609. Under Argentinian Law, Fernando Ronchetti proposes a limitation on forced shares as a way to improve the quality of life of the elderly. Alfredo Fernando Roncheti, "Calidad de vida en la ancianidad: más libertad de testar es más justiciar,” Oñati Socio-Legal Series 1, no. 8 (2011).

14 Ángeles Parra, "Legítimas, libertad de testar y transmisión de un patrimonio," $A F$ DUDC, no. 13 (2009): 481-554. 
does not usually depend on the need of the heir, but on a mere family tie. Other authors ${ }^{15}$, however, highlighted that a lack of forced shares could potentially damage interests of minor children, taking into account that current family models (e.g. parenting outside marriage, cohabitation) does not ensure that someone's estate remains in the family and thus children are not protected in patrimonial terms. Lamarca ${ }^{16}$ concluded that forced shares actually protect the core value of solidarity between generations, which is not quantifiable or capable of evaluation in market terms. Moreover, it may cause inequality between children and family conflicts ${ }^{17}$.

This paper analyses the legal framework of forced shares in Spain, taking into account the differences among Spanish Autonomous Communities (hereinafter CA; NUTS II); examines the grounds of exclusion of this right and, in particular, the possibility to exclude it due to a lack of personal relationship with the beneficiary, while discussing the need to keep or not this institution in the light of current family models. To do so, this paper follows a dogmatic analysis of current Spanish legislation, discusses last judgements on the possibility to exclude forced heirs due to a lack of relationship and makes a comparative law analysis with other EU jurisdictions.

\section{LEGAL FRAMEWORK OF FORCED HEIRSHIP IN SPAIN}

The Spanish Constitution foresees in Article 149.1.8 that, although the State has the exclusive power on civil law, Spanish CA may conserve, modify and develop their own civil law rules, where they existed at that time (1978). That is why successions law may vary depending on the per-

15 Ralph C. Brashier, "Disinheritance and the Modern Family," Case Western Reserve Law Review 45, Issue 1 (1994). Note that this author is focused on common law succession law, which has traditionally protected in a higher degree the freedom of disposal.

16 Albert Lamarca i Marquès, "We Are Not Born Alone and We Do Not Die Alone: Protecting Intergenerational Solidarity and Refraining Cain-ism Through Forced Heirship," Oñati Socio-legal Series 4, no. 2 (2014): 264-282.

17 José Luís Lacruz Berdejo, Elementos de Derecho civil. V. Sucesiones (Madrid: Dykinson, 2004), 318. 
sonal law applicable to the descendant (Article 9.1 Spanish Civil Code ${ }^{18}$, hereinafter $\mathrm{CC}^{19}$ ). Thus, several Spanish regions have their own civil law rules on successions law, such as the Basque Country, Catalonia, Aragón or Navarre. In its turn, the CC also has a general regulation of succession law and, in particular, of forced heirship, which, as said, will be of application to those Spanish citizens that do not have the personal law of a region that regulated its own civil law (e.g. in Andalusia, Murcia or Castilla-LaMancha).

In the CC, the so-called 'legitima' is a non-disposable share of the deceased's goods, being reserved to the forced heirs (Article $806 \mathrm{CC}{ }^{20}$. It is also possible to give to the heirs their share before the testator dies, as donations made to descendants are considered part of this forced share (Article 819 CC). According to Article $813 \mathrm{CC}$, the testator may not deprive his heirs of their reserved portion except in the cases expressly determined by law (see below 3.1. General exclusion grounds).

Forced heirs, i.e. the relatives that have the right of a share of the deceased's estate, are:

- The sons and daughters of the deceased. If one of them died before the testator, then the condition of 'forced heir' is attributed to grandchildren.

- If the deceased had no offspring, the forced heirs are his parents and, in case they died before the testator, other ascendants (e.g. grandparents).

- The surviving spouse $e^{21}$.

18 Spain. Codigo civil español. Royal Decree of 24.7.1889. Spanish Official Gazzete núm. 206, 25.7.1889.

19 Personal law is attributed, within Spain and generally speaking, according to one's CA with its own historical civil law; if none, the common civil law for Spain is applied, that is, the CC rules.

${ }_{20}$ Regardless of the fact that the CC uses the term 'forced heirs', the beneficiaries are not considered 'heirs': they are not entitled to a share of the testator's estate, but to claim a share of the goods. Juan José Rivas Martínez, Derecho de sucesiones común. Estudios sistemático y jurisprudencial. Tomo I. (Valencia: Tirant lo Blanch, 2020), 1323.

21 The CC does not include legal partners as forced heirs. However, civil law rules of some Spanish CA do foresee this right for legal partners, such as in Catalonia or the Basque Country. 
This basically follows the rule that 'love first descends, then ascends, and, finally, spreads sideways', included in Novel 118 of Justinian for $a b$ intestato successions.

Although all of them are considered forced heirs, not all of them have the right to the same share. In general terms, the testator's estate is divided in the following shares:

- 'Tercio de legitima' (third forced share): this share is intended to be given to the forced heirs in any case.

- 'Tercio de mejora' (third for betterment): this share is intended to be given to improve the assets corresponding to one or more descendants in front of the other ones.

- 'Tercio de libre disposición': this is the third share, which may be freely disposed by the testator.

First-degree descendants will be entitled to two thirds of the estate (including the so-called 'tercio de legitima' and 'tercio de mejora'), regardless of the number of descendants. The testator, however, may reserve the 'tercio de mejora' for one or more specific forced heirs, so that they are more benefited ahead of the other descendants.

In case the deceased does not have descendants, but ascendants, they will be entitled to a half of the deceased estate (Article 809 CC); but, if there is also a surviving spouse, the parents will only be entitled to a third part of the deceased estate. In case the testator leaves by any title less than the reserved share that corresponds to the forced heir, they may request a complement to receive at least what the CC foresees (Article $815 \mathrm{CC}$ ).

In relation to the surviving spouse, although considered a 'forced heir', they are not entitled to receive the ownership of the deceased estate, but a usufruct, and provided that they were not divorced or separated from the deceased (Article $834 \mathrm{CC}$ ). The share that will be subject to this legal usufruct will depend on the number of the forced heirs having the right to receive an estate's share:

- If there exist children or descendants, the widow/er will be entitled to the usufruct of a third of the descendant's estate, the so-called 'tercio de mejora' (Article $834 \mathrm{CC}$ ).

- If the testator does not have any descendants when he or she dies, but parents and ascendants, the widow/er will be entitled to a usufruct over half of the testator's estate (Article 837 CC). 
- If the testator neither have descendants nor ascendants when dying, the widow/er will be entitled to a usufruct over two thirds of the testator's estate (Article $838 \mathrm{CC}$ ).

Table 1 summarizes forced shares in the Spanish Civil Code:

Table 1. Summary of the forced heirs and their forced share

\begin{tabular}{|c|c|c|c|}
\hline $\begin{array}{l}\text { Forced } \\
\text { heirs }\end{array}$ & $\begin{array}{c}\text { Sons/daughters and } \\
\text { descendants }\end{array}$ & $\begin{array}{c}\text { Parents } \\
\text { and ascendants }\end{array}$ & $\begin{array}{l}\text { Surviving } \\
\text { spouse }\end{array}$ \\
\hline Share & $\begin{array}{l}\text { Two thirds (the 'tercio } \\
\text { de legitima' and the } \\
\text { 'tercio de mejora'). } \\
\text { One of the thirds } \\
\text { ('tercio de legitima') } \\
\text { shall be distributed } \\
\text { proportionally among } \\
\text { the sons/daughters } \\
\text { (or, if one of them died, } \\
\text { his/her descendant will } \\
\text { receive the share). } \\
\text { However, } \\
\text { the testator may use } \\
\text { one of the thirds } \\
\text { ('tercio de mejora') for } \\
\text { the benefit of only one } \\
\text { of the beneficiaries. }\end{array}$ & $\begin{array}{l}\text { The share that parents } \\
\text { are given depends } \\
\text { on the existence of } \\
\text { a surviving spouse. } \\
\text { If the deceased was } \\
\text { not married, parents } \\
\text { will be entitled to half } \\
\text { of the testator estate. } \\
\text { If the testator was } \\
\text { married when he or } \\
\text { she dies, parents will } \\
\text { receive a third part of } \\
\text { the testator's estate. }\end{array}$ & $\begin{array}{l}\text { He or she has the right } \\
\text { to receive a legal usufruct } \\
\text { over a share of } \\
\text { the testator's estate. } \\
\text { When the testator has } \\
\text { children or descendants, } \\
\text { the surviving spouse will } \\
\text { be entitled to the usufruct } \\
\text { of one third (the one } \\
\text { corresponding to the } \\
\text { 'tercio de mejora'). } \\
\text { If the testator does not } \\
\text { have descendants but } \\
\text { ascendants, the usufruct } \\
\text { of the surviving spouse } \\
\text { will cover half of } \\
\text { the testator's estate. } \\
\text { If the testator does } \\
\text { not have descendants } \\
\text { or ascendants, then } \\
\text { the usufruct will cover } \\
\text { two thirds of the estate. }\end{array}$ \\
\hline Condition & $\begin{array}{l}\text { They are the first degree } \\
\text { of forced heirs, so sons/ } \\
\text { daughters are always } \\
\text { entitled to a forced } \\
\text { share, provided that } \\
\text { they are not unworthy } \\
\text { to inherit (see below). }\end{array}$ & $\begin{array}{l}\text { They are forced heirs } \\
\text { only if the testator does } \\
\text { not have descendants. }\end{array}$ & $\begin{array}{l}\text { He or she shall not be } \\
\text { divorced or separated } \\
\text { from the testator at } \\
\text { the moment of death. }\end{array}$ \\
\hline
\end{tabular}

Source: own elaboration. 
As commented above, some Spanish regions have their own civil law rules regarding succession law and therefore forced shares. Here are some examples:

- Basque country: the forced heirs are descendants and the surviving spouse or the legal partner, but not his parents (Article 47 Act 5/2015, on the Civil Law of the Basque Country ${ }^{22}$ ): the descendants are entitled to a third share of the testator's estate, and the surviving spouse or the legal partner ${ }^{23}$ to the usufruct of half of the deceased estate. However, if the deceased does not have children or descendants, the usufruct of the surviving spouse or legal partner will be extended to two thirds of the deceased estate. Contrary to what the CC foresees, in the Basque Country the deceased may attribute the forced share to only one or more of the forced heirs (therefore, she may exclude some of them without any ground), and law admits the waive of a forced shared before the testator's death (Article 48 Act 5/2015). In addition, and due to historical reasons, there are some differences in the regulation on forced heirship in Bizkaia and in the municipalities of Aramaio and Llodio: in this region and these municipalities, the forced share represents four fifths of the deceased estate.

- Navarra: in this region, the deceased has full freedom to dispose his succession by will, so that descendants cannot claim any type of goods or economic value (Law 267, included in Act 1/1973, on the Compilation of Civil Law of $\mathrm{Navarra}^{24}$ ).

- Aragón: contrary to the CC, the forced share in this region corresponds to half of the deceased estate; however, the testator may exclude some of the forced heirs without the need of giving a particular reason (Article 486 Legislative Decree 1/2011, on the Code of civil law of Aragón $\left.{ }^{25}\right)$. The condition of forced heir is only given to descendants, and the forced share may be waived by them before the death of

22 Spanish Official Gazette (Boletín Oficial del Estado, BOE) núm. 176, 24.7.2015.

23 The condition of legal partner depends on each Autonomous Community. In the Basque Country, legal partners shall be registered in a Registry of Legal Partners to be considered as such, according to Article 3 Act 2/2003, which regulate legal partners in the Basque Country (BOPV núm. 100, 23.5.2003).

24 BOE núm. 57, 7.3.1973.

25 Official Gazette of Aragón, núm. 67, 29.3.2011. 
the testator (Article 493 Legislative Decree 1/2011), contrary to what is established in Article 816 CC.

- Catalonia: in the Fourth Book of the Catalan Civil Code ${ }^{26}$ (hereinafter, CCC), forced heirs are children and descendants, or parents or ascendants (when the deceased have no children when he or she dies). So, forced heirs are either testator's sons/daughters (or grandchildren, when sons and daughters had died before the testator) or testator's parents (or grandparents, when the testator's parents had died before her). In any case, the forced share corresponds only to one quarter of the testator's estate, regardless of the number of forced heirs (Article 451-5 CCC). Note that the surviving spouse or the legal partner is not considered a forced heir, but CCC provides him/her with a claim in order to be compensated for economic imbalance ${ }^{27}$ and has the right to the so-called 'cuarta vidual: this is one quarter of the testator's estate that the spouse may obtain if he or she does not have sufficient financial resources to meet their needs (Article 452-1 CCC).

\section{THE POSSIBILITY TO EXCLUDE FORCED HEIRS DUE} TO A LACK OF PERSONAL RELATIONSHIP WITH THE DECEASED

\subsection{General exclusion grounds}

As we have seen above, the forced heirship institution for general civil law in Spain is broad (a bit less in Catalonia and inexistent in Navarre), granting up to two thirds of deceased goods and considering forced heirs not only descendants, but also ascendants and the surviving spouse. That is why some Spanish authors consider that, at least, forced heirship should be limited ${ }^{28}$.

26 BOE núm. 190, 7.8.2008.

27 M. del Carmen Gete-Alonso Calera, Josep Llobet Aguado, Judith Solé Resina and Maria Ysàs Solanes, Derecho de sucesiones vigente en Cataluña. 3rd ed. (Valencia: Tirant lo Blanch, 2011), 268.

28 See an analysis of the Spanish authors at: Parra, "Legítimas, libertad de testar y transmisión de un patrimonio". 
The fact is that, even though forced heirship is broad, the CC includes several causes to allow the testator to lawfully exclude some relatives from this right. These grounds of exclusion could serve to guarantee the support of the family, while penalizing those relatives who have not contributed to testator's wellbeing.

Among others, the grounds regulated in the $\mathrm{CC}$ are:

- Unworthiness to inherit (Article 756 CC): when the forced heir committed a crime against the testator (e.g. death, violence, crimes against the moral or sexual integrity, false reports, oblige the testator to make a will, abuse...). For example, in SAP Valladolid 7.10.201329, the forced heir abandoned his daughter when she was minor.

- Specific grounds of exclusion for descendants (Article $853 \mathrm{CC}$ ): when the forced heir is the testator's descendant, the testator may exclude them in case of denial of alimony and abuse or mistreatment of the testator. See SAP Murcia 11.6.1999 ${ }^{30}$, where descendants denied alimony to their father and thus the Court considered that they were not entitled to a forced shared.

- Specific grounds of exclusion for ascendants (Article $854 \mathrm{CC}$ ): when the forced heir is the testator's ascendant, the testator may also exclude them in case of denial of alimony, when the ascendant lost parental responsibility and when one of the parents committed a crime against the other parent's life (e.g. cases of gender violence between parents).

- Specific grounds for the surviving spouse: in this case, apart from not providing alimony to the testator and the commitment of a crime against the testator's life, surviving spouses may be also excluded due to a serious and repeated breach of marital duties (i.e. helping and treating the other spouse with respect, being faithful and sharing domestic responsibilities and children's care, Article 67 and 68 CC).

The testator may only use these grounds to exclude forced heirs (Article $848 \mathrm{CC}$ ). In addition, they are quite narrow, and they usually require a previous judgement proving the crime, a breach of family obligations, etc. However, the Spanish Supreme Court (TS) has given during last years a new interpretation of the exclusion ground due to 'abuse', as was seen in

\footnotetext{
29 JUR $2013 \backslash 325110$.

30 AC $1999 \backslash 7153$.
} 
STS 3.6.2014 ${ }^{31}$ : according to the TS, Article 848 CC, when mentioning as an exclusion ground the 'abuse' (maltrato de obra), a psychological abuse should also be included. Recent case law ${ }^{32}$ considers that the psychological abuse is related with someone's dignity (Article 10 Spanish Constitution, $\mathrm{CE}$ ). In order to exclude a forced heir due to abuse, it is necessary that testator's mental health is affected, and that the abuse is only attributable to the forced heir. Does psychological abuse include the lack of relationship? Although a mere lack of relationship does not imply per se a phycological abuse $^{33}$, some minor judgments consider that the mental health of the testator may be affected in this case. For example, at SAP Badajoz 20.4.2020 ${ }^{34}$ a forced heir only phoned his father twice per year and did not visit him when he was in the hospital, thus being excluded from receiving his forced share. In SAP Castellón 29.11.2010 35 the Court considers that there exists an abuse due to a lack of relationship for 8 year $^{36}$, involving an emotional abandonment of the deceased. In SAP Valencia 8.2.2018 ${ }^{37}$, a forced heir was excluded because of a lack of relationship caused by past judicial claims against his mother (the deceased). And SAP Vizcaya 5.11.2016 ${ }^{38}$ considers that a phycological abuse may include a lack of affection, disparagement, and elder abuse and neglect. However, not any type of lack

31 ECLI:ES:TS:2014:2484. After this judgment, there were other ones confirming this interpretation, such as STS 13.5.2019 (ECLI:ES:TS:2019:1523). Before this interpretation, regional courts did not consider a lack of relationship as a ground to exclude forced heirs. See SAP Asturias 7.11. 2004 (JUR 2004166268), SAP Pontevedra 28.4.2008 (JUR 2008\303852) and SAP Córdoba 28.9.2011 (AC 2011\790), considering that the hostility and a lack of affection was not a ground to exclude a forced heir.

32 STS 19.2.2019 (Roj: STS 502/2019) and SAP Asturias 10.10.2019 (AC 2019\1951).

33 See Silvia Algaba Ros, "Maltrato de obra y abandono emocional como causa de desheredación," Indret, (April 2015) and M. del Carmen González Carrasco, "Comentario a la Sentencia del Tribunal Supremo de 3 de junio de 2014. Desheredación por maltrato psicológico," Cuadernos Civitas de Jurisprudencia Civil, no. 97 (2015).

34 AC 2020\1022.

35 JUR 2020\152408.

36 Likewise, SAP Sevilla 7.3.2019 (JUR 2019\177885) also admits the exclusion due to a lack of relationship for 30 years.

37 AC $2018 \backslash 441$.

38 AC 20161292. 
of relationship may bring the exclusion of the forced heir: in SAP Valencia 20.9.2018 ${ }^{39}$, the emotional abandonment was only a perception of the deceased; the forced heir -her daughter- tried on several occasions to take care of her, but the deceased denied the personal contact.

As a conclusion, even though the CC does not include a lack of relationship as a ground to exclude forced heirs, this lack of relationship caused by the forced heir may have caused in the deceased some type of psychological abuse and an attack to their dignity, for a long period of time $\mathrm{e}^{40}$. In this case, it would be possible to exclude a forced heir that caused this damage. However, the existence of the ground shall be interpreted by the court, which gives rises to the judicialization of these cases.

\subsection{Exclusion of the forced share due to a lack of personal relationship in the Catalan Civil Code}

The lack of personal relationship, which is not explicitly included in the $\mathrm{CC}$ as an exclusion ground, is nevertheless considered as such whenever the succession law from Catalonia is applicable to the deceased, i.e. his personal law is "Catalan", according to arts. 14 and 16 CC rules.

CCC foresees grounds for exclusion that, generally speaking, are similar to those ones included in Articles 756, 853 and 854 CC. But in addition, it also regulates the exclusion of forced heirship when there is a 'a clear and continuous absence of a family relationship between the deceased and the beneficiary, if it is caused solely by the beneficiary' (Article 451-17.e CCC). This exclusion ground is applicable to any type of forced heir, i.e., descendants and ascendants.

In this case, it is also the testamentary heir (not the forced one) who has to prove that the forced heir did not have a personal relationship with the deceased, if the forced heir challenges the will. And, in addition, this lack of relationship shall be:

39 AC 2018\1687.

40 Algaba Ros, "Maltrato de obra y abandono emocional como causa de desheredación,” 19. 
- Clear/obvious (manifiesta): it suggests that, in cases where the forced heir has at least some type of relationship (e.g. visits one or twice per year the testator), this exclusion ground would not be applicable.

- Continuous (continuada): it is not enough that the lack of relationship cannot be a temporary situation. As far as the CCC does not establish a minimum term, the courts will interpret whether the lack of relationship was continuous or not. In fact, judgements where this exclusion ground is accepted does not require a certain minimum period of time, but they apply this ground on a case-by-case basis. For example, in SAP Barcelona 17.11.2017 ${ }^{41}$, the lack of relationship lasted 18 years, while in SAP Barcelona 19.5.2016 ${ }^{42}$ only two years.

- Caused by the beneficiary: the lack of relationship shall be caused exclusively by the forced heir ${ }^{43}$.

As some authors stated ${ }^{44}$, this exclusion ground gives more room for the judge to decide and thus to interpret. In fact, these three requirements are difficult to be interpreted: what is a clear lack of relationship? If the testator and the forced heir are one year without contact, is this considered 'continuous'? May a lack of relationship be caused by only one person?

That is why there exist several judgements interpreting these requirements. In principle, a mere weak relationship is not included within this exclusion ground ${ }^{45}$. The high court of justice of Catalonia (TSJC) considered in Judgement 8.1.2018 ${ }^{46}$ that the lack of relationship was neither continuous nor caused by the beneficiary in a case where the two daughters of the testator had some sort of contact with him through social media. Although they had no contact for more than 20 years, during the last years

41 AC 2017\1726.

42 AC 2016\1572.

43 According to Arroyo and Farnós, this is difficult to be assessed and it reduces the applicability of this exclusion ground. Esther Arroyo and Esther Farnós, "Entre el testador abandonado y el legitimario desheredador ¿A quién prefieren los tribunales?,” Indret, no. 2 (2015): 18.

44 Paloma De Barrón Arniches, "Libertad de testar y desheredación en los Derechos civiles españoles," Indret, no. 4 (2016): 45.

45 See SAP Barcelona 10.10.2019 (JUR 2019\296264), where there was a weaker relationship due to a conflict caused by a new sentimental relationship of the testator.

46 RJ 2018\1503. 
the daughters contacted their father through the internet, and they eventually phoned him. In Judgement TSJC 31.5.2018 ${ }^{47}$, the court also considered that this exclusion ground was not applicable. In this case, the father abandoned the family home when children were underaged, and he did not try to keep the contact with them since then. Also, in case of family disputes that ended up in a lack of family relationship, courts usually consider that this is not attributable exclusively to the forced heir ${ }^{48}$.

As a conclusion, although the Catalan legislator decided to introduce this exclusion ground to adapt law to social changes (in particular, to changes in traditional family care), the evidence of a clear and continuous lack of relationship attributable to the forced heir is problematic, which may increase litigation.

\section{A BRIEF COMPARATIVE PERSPECTIVE}

Legislation on forced shares is different among jurisdictions in several ways: on the reserved share entitled to forced heirs, on the nature of the forced share, on the methods for calculating it or on the exclusion grounds ${ }^{49}$. Spanish inheritance law regarding forced shares is considered one of the most restrictive systems due to its extension to ascendants and the amount granted ${ }^{50}$; however, note that some of the CA regimes reduced this right, such as Navarre, which do not recognize forced shares, or Catalonia, recognizing up to $25 \%$ of the value.

Most EU countries also regulate forced shares in favour of certain relatives, but it is not common to recognize them to ascendants ${ }^{51}$. For exam-

47 RJ $2018 \backslash 3912$.

48 See SAP Barcelona 31.3.2016 (AC 2016\1043), SAP Barcelona 19.6.2020 (JUR 2020\236941), SAP Lleida 19.5.2020 (AC 2020\1179) and SAP Barcelona 26.7.2018 (JUR 2018\247316), where the relationship was worse after a family dispute.

49 Lamarca i Marquès, "We Are Not Born Alone and We Do Not Die Alone".

50 Sergio Cámara Lapuente, "Chapter 6. Forced Heirship in Spanish Law," Comparative Succession Law. Vol. III, ed. Kenneth Reid, Marius J. de Waal, and Reinhard Zimmermann (Oxford: Oxford University Press, 2020).

51 René Foqué and Alain Verbeke, "Conclusions. Towards an open and flexible imperative inheritance law," in Imperative Inheritance Law in a Late-Modern Society, ed. Chris- 
ple, descendants and the spouse or legal partner ${ }^{52}$ are entitled to half of the intestate portion in Austria ( $\$ 760$ Allgemeines bürgerliches Gesetzbuch, $\left.\mathrm{ABGB}^{53}\right)$. The same right applies in descendants and the spouse in France (Article 913 and ff. French Civil $\operatorname{Code}^{54}$ ), excluding ascendants from the forced shares since $2006^{55}$. In this case, the amount varies depending on the number of beneficiaries: if the testator has one son/daughter, the latter will be entitled to half of the testator's estate. If he has two son/ daughters, they will be entitled to two thirds: if he has three or more sons/ daughters, they will be entitled to three quarters (Article 913 French Civil Code); in case the testator does not have surviving descendants, the spouse will be eligible to a quarter of the testator's estate (Article 914 French Civil Code). In Germany, the spouse, descendants and parents are the ones entitled to the forced share ( $\$ 2303$ Bürgerliches Gesetzbuch56, BGB). In the Netherlands, only descendants of the testator are forced heirs (Article 4:63 Dutch Civil Code ${ }^{57}$ ), who are eligible for one half of the value of the testator's estate divided by the number of intestate heirs (Article 4:64.1 Dutch Civil Code); but the spouse is entitled to continue using the residential space (Articles 4:28 and ff. Dutch Civil Code) ${ }^{58}$.

In contrast, common law countries have not traditionally foreseen forced share. According to Németh ${ }^{59}$, '( $\mathrm{t}$ )he individualist anthropology of the Anglo-Saxon culture and the almost unlimited natural right of own-

toph Castelein, René Foqué, and Alain Verbeke, European Family Law Series (Mortsel: Intersentia, 2009), 203-221.

52 Before 2015, ascendants were also entitled to a forced shared, but this changed with Erbrechts-Änderungsgesetz 2015 (BGBl. I Nr. 87/2015).

53 Austria. Allgemeines bürgerliches Gesetzbuch. JGS Nr. 946/1811.

54 France. Code civil des Français. 21.3.1804.

55 France. Loi $n^{\circ}$ 2006-728 du 23 juin 2006 portant réforme des successions et des libéralités (NOR: JUSX0500024L).

56 Germany. Bürgerliches Gesetzbuch. Published in the Reich Gazette on 24 August 1896.

57 The Netherlands. Burgerlijk Wetboek. Boek 4 (BWBR0002761).

58 See the protection of the surviving spouse in the Netherlands in BarbaraE. Reinhartz, "Recent Changes in the Law of Succession in the Netherlands: On the Road towards a European Law of Succession?," Electronic Journal of Comparative Law 11, no. 1 (2007).

59 Ildikó Németh, "The Successions in Europe. A Contribution to the Classification and Unification of the Succession Systems in Europe," ELTE Law Journal, no. 2 (2015): 109-126. 
ership is expressed by the succession law in the way in which in England, Wales and Northern Ireland, the reserved share of it does not exist'. The same happens in the United States, where, in most of the States, law prioritize the individual freedom of will over property within the family ${ }^{60}$ : this has been criticized by some authors, such as Brashier ${ }^{61}$, who stated that 'Legislatures have yet to realize the serious consequences of permitting the total disinheritance of these children: minor children could be left behind in the event of their parents' death, as nobody would care for them (particularly, in cases of single-parent families).

According to Reid, de Waal and Zimmermann ${ }^{62}$, in countries with forced shares, the possibility of disinheritance is not commonly recognized by law. They confirm that specific disinheritance for forced shares does not exist in France, Italy, the Netherlands or Belgium, but the forced heir can be excluded if he or she is unworthy to inherit. Nevertheless, general grounds of unworthiness are usually limited to the existence of criminal offences against the testator or their relatives, such as major offences or interference with the testator will (e.g. $\$ \$ 2339$ and 2345.2 BGB and Article 4:3 Dutch Civil Code ${ }^{63}$ ).

In addition, the possibility to disinherit due to a lack of family relationship is not a common practice in these countries. Only Austria has a similar ground in $\$ 776 \mathrm{ABGB}$, which establishes that the testator may reduce the forced share to half if he and the beneficiary did not at any time or, at least, for a long period before the death of the testator, have a close family relationship ${ }^{64}$. Also, the State of Louisiana, in the United States, is

${ }^{6}$ Vincent D. Rougeau, "No Bonds but Those Freely Chosen: An Obituary for the Principle of Forced Heirship in Americal Law," Civil Law Commentaries 1, Issue 3 (2008).

61 Brashier, "Disinheritance and the Modern Family," 89.

62 Reid, de Waal, and Zimmermann, "Comparative perspectives," 769.

63 Although, in the case of Dutch law, unworthiness grounds may be broadly interpreted: in Judgement of the Hof Amsterdam 15.8.2002 (NJ 2002/53), a grandchild pretended to receive a forced share from his grandmother. However, it was possible to exclude him from this right, since the grandchildren killed his parents some years ago (the grandmother's children). Even when the Dutch Civil Code did not include this type of criminal offence as an unworthiness ground, the Court decided to exclude the forced share.

64 Free translation from the German: Der Verfügende kann den Pflichtteil letztwillig auf die Hälfte mindern, wenn er und der Pflichtteilsberechtigte zu keiner Zeit oder zumindest 
unique among the states in this country in regulating forced shares (due to, among others, historical and religious reasons $s^{65}$, adapting this institution from French and Spanish Law); but in 1999 it introduced the possibility to exclude this mandatory right for family members due to a lack of relationship. According to Article 1621 of the Civil Code of Louisiana, 'A parent has just cause to disinherit a child if (8) the child, after attaining the age of majority and knowing how to contact the parent, has failed to communicate with the parent without just cause for a period of two years, unless the child was on active duty in any of the military forces of the United States at the time'. In this case, the responsibility to keep the contact with the testator (parent) is attributed to the child; also, the Louisiana Civil Code regulates a minimum term of a lack of family relationship, intended to prevent disputes on that, such as the ones happening in Spain and, in particular, in the CA of Catalonia.

\section{CONCLUDING REMARKS}

Forced shares are considered a mechanism within succession law to keep intergenerational solidarity, but new family models and changes in family care increased the debate on their existence. In particular, the COVID-19 pandemic highlighted that many older people died in isolation, without family support, but part of their estate still had to be assigned to some family members.

Traditionally, the regulation of forced shares varied between common law and civil law jurisdictions. The first ones prioritized the freedom of individuals to decide upon the destination of their estates (e.g. in the United States or in England), whether civil law countries (or states, such as Louisiana) usually included forced shares within succession law. That is why in most EU countries, forced shares are recognized, but with differences regarding their nature, amount or beneficiaries.

über einen längeren Zeitraum vor dem Tod des Verfügenden nicht in einem Naheverhältnis standen, wie es zwischen solchen Familienangehörigen gewöhnlich besteht'.

65 Rougeau, "No Bonds but Those Freely Chosen: An Obituary for the Principle of Forced Heirship in Americal Law,” 2. 
Forced shares in Spain are considered one of the most extensive ones, since even parents and other ascendants of the deceased are beneficiaries (which is not a common practice in other EU countries), and it does regulate several exclusion grounds. According to the CC, a forced heir may be excluded if he or she commits abuse against the deceased. However, the Spanish Supreme Court interpreted in 2014 that the term 'abuse' may include a phycological one, which may appear in cases of a lack of relationship. Moreover, in some Spanish CA, forced shares are quite limited: in the CA of Catalonia within Spain, a new ground of exclusion due to a lack of relationship was regulated in 2010, which is not common in other EU countries. And in Navarre, forced shares do not exist. Therefore, Spanish legislation is now more prone to the freedom of will in these situations, and abandoned elderly could exclude forced shares in these cases. Nevertheless, this legislation is still quite restrictive for the testator due to the amount that beneficiaries are granted (up to two thirds if the CC is applicable). It is also questionable whether the Spanish regime is actually protecting the rights of minor children or granting intergenerational solidarity for family members in need, since forced shares do not depend on how old the beneficiaries are or their wealth.

In addition, the exclusion ground due to a lack of family relationship is subject to interpretation, which does not provide legal security to citizens. First, under CC, because each judge shall assess whether a psychological abuse has been committed. Second, because the CCC requires a continuous and clear lack of relationship, caused solely by the beneficiary. These concepts are interpreted by courts on a case-by-case basis, which may increase litigation, providing different results for similar cases. This situation suggests the need to better regulate this exclusion ground, e.g. introducing objective requirements for excluding forced heirs (such as in Louisiana, where there exist a minimum term for the lack of relationship) or defining what the term 'psychologic abuse' means. Finally, while new elderly care models suggest that forced shares should be limited, a complete restriction may harm minor children or vulnerable family members, thus both interests should be taken into account in this debate. 


\section{REFERENCES}

Algaba Ros, Silvia. "Maltrato de obra y abandono emocional como causa de desheredación." Indret (April 2015): 1-26.

Alventosa Del Río, Josefina, et al. "Aspectos sustantivos del derecho hereditario."

In Derecho de sucesiones, edited by Josefina Alventosa Del Río, and María Elena Cobas Cobiella, 609-644. Tirant lo Blanch: Valencia, 2017.

Angel, Ronald J., and Jaqueline Angel. Family, intergenerational solidarity and post-traditional society. New York and London: Routledge, 2018.

Arroyo, Esther, and Esther Farnós. "Entre el testador abandonado y el legitimario desheredador ¿A quién prefieren los tribunales?”" Indret, no. 2 (2015): 1-32.

Bengston, Vern, Gerardo Marti, and Robert Roberts. "Age-group relationships: Generational equity and inequity." In Parent-child relations throughout life, 283-308. New York and London: Routledge, 1991.

Brashier, Ralph C. "Disinheritance and the Modern Family." Case Western Reserve Law Review 45, Issue 1 (1994): 83-183.

Cámara Lapuente, Sergio. "Chapter 6. Forced Heirship in Spanish Law." In Comparative Succession Law, Vol. III, edited by Kenneth G.C. Reid, Marius J. de Waal, and Reinhard Zimmermann, 139-174. Oxford: Oxford University Press, 2020.

De Barrón Arniches, Paloma. "Libertad de testar y desheredación en los Derechos civiles españoles." Indret, no. 4 (2016): 1-57.

Domènech-Abella, Joan, et al. "Loneliness and Depression in the Elderly: The Role of Social Network." Social Psychiatry and Psychiatric Epidemiology 52, no. 4 (April 2017): 381-90. https://doi.org/10.1007/s00127-017-1339-3.

Fernando Roncheti, Alfredo. "Calidad de vida en la ancianidad: más libertad de testar es más justiciar." Oñati Socio-Legal Series 1, no. 8 (2011): 1-18.

Foqué, René, and Alain Verbeke. "Conclusions. Towards an open and flexible imperative inheritance law." In Imperative Inheritance Law in a Late-Modern Society, edited by Christoph Castelein, René Foqué, and Alain Verbeke, 203-244. European Family Law Series. Mortsel: Intersentia, 2009.

Gete-Alonso Calera, M. del Carmen, Josep Llobet Aguado, Judith Solé Resina, and Maria Ysàs Solanes. Derecho de sucesiones vigente en Cataluña. 3rd ed. Valencia: Tirant lo Blanch, 2011.

González Carrasco, M. del Carmen. "Comentario a la Sentencia del Tribunal Supremo de 3 de junio de 2014. Desheredación por maltrato psicológico.” Cuadernos Civitas de Jurisprudencia Civil, no. 97 (2015): 277-288. 
Krstić, Novak. "A doctrinal justification of the institution of compulsory share in modern legislature." Teme, no. 10 (February 2020). https://doi.org/10.22190/ TEME200207092K.

Lacruz Berdejo, José Luís. Elementos de Derecho civil. V. Sucesiones. Madrid: Dykinson, 2004.

Lamarca i Marquès, Albert. "We Are Not Born Alone and We Do Not Die Alone: Protecting Intergenerational Solidarity and Refraining Cain-ism Through Forced Heirship.” Oñati Socio-legal Series, no. 2 (2014): 264-282.

López López, Ángel M., and Rosario Valpuesta Fernández, eds. Derecho de sucesiones. Valencia: Tirant lo Blanch, 2015.

Németh, Ildikó, "The Successions in Europe. A Contribution to the Classification and Unification of the Succession Systems in Europe." ELTE Law Journal, no. 2 (2015): 109-126.

Parra, M. Ángeles, "Legítimas, libertad de testar y transmisión de un patrimonio." AFDUDC, no. 13 (2009): 481-554.

Rivas Martínez, Juan José. Derecho de sucesiones común. Estudios sistemático y jurisprudencial. Tomo I. Valencia: Tirant lo Blanch, 2020.

Reid, Kenneth G.C., Marius J. de Waal, and Reinhard Zimmermann. "Comparative perspectives." In Comparative Succession Law. Vol. III, edited by Kenneth G.C. Reid, Marius J. de Waal, and Reinhard Zimmermann, 740-776. Oxford: Oxford University Press, 2020.

Reinhartz, Barbara E. "Recent Changes in the Law of Succession in the Netherlands: On the Road towards a European Law of Succession?." Electronic Journal of Comparative Law 11, no. 1 (2007): 1-18.

Rougeau, Vincent D. "No Bonds but Those Freely Chosen: An Obituary for the Principle of Forced Heirship in Americal Law." Civil Law Commentaries 1, Issue 3 (2008): 1-37. 